\title{
Socio-economic Diagnosis of Ornamental Horticulture in Togo
}

\author{
Raoufou Radji (Corresponding author) \\ Laboratoire de Biologie et Ecologie végétale, Université de Lomé, BP 1515, Togo \\ Tel: 228-9004-5114Ｅ-mail: pradji@ hotmail.com
}

Patrick Van Damme

Laboratoire d'agronomie tropicale et subtropicale et d'ethnobotanique

Universiteit Gent, Coupure links 653, 9000, Togo

E-mail: Patrick.VanDamme@UGent.be

Kouami Kokou

Laboratoire de Biologie et Ecologie végétale, Université de Lomé, BP 1515, Togo

Tel: 228-9002-0411Ｅ-mail: kokoukouami@ hotmail.com

Koffi Akpagana

Laboratoire de Biologie et Ecologie végétale, Université de Lomé, BP 1515, Togo

Tel: 228-2221-3500Ｅ-mail: koffi2100@gmail.com

Received: August 3, 2012 Accepted: August 17, 2012

doi:10.5296/jbls.v4i1.2186 URL: http://dx.doi.org/10.5296/jbls.v4i1.2186

\begin{abstract}
Production systems in ornamental horticulture in Togo are very diverse in terms of speculation, access to land (variable surfaces, direct or indirect forms of tenure, acquisition methods and land use, etc.) and socio-economic profiles of farmers (men, women, young, old, people with little or no qualifications, rural to urban, etc.). The family horticultural
\end{abstract}


production system, which represents over $90 \%$ of 55 horticultural farms of this study, is the main production system. It is characterized by areas of less than 0.1 hectare and farms in relative land insecurity ( $97 \%$ of land used to belong to the state). Throughout the system, there is a salaried labor representing 5-8\% of turnover. Temporary and permanent employees are paid on weekends or at the end of the month. Farmers use gardening equipment and processing plant more or less modern including clippers, shears, pruners and sprayers. Production units provide direct employment (more than 3 employees per unit) and directly to several hundred people. Horticulture in urban and peri-urban areas improves the living conditions of farmers (income) and the population (embellishment of streets, maintenance or creation of green areas buffer) despite some negative externalities associated particularly with the use of prohibited pesticides and uncontrolled use of spaces along the roads. Its survival is threatened by many constraints, including the extension of urban housing and road building. In Togo, beneficial effects of ornamental horticulture may be more noticeable if the political authorities, private stakeholders and the researchers work together to organize the sector. It could thus participate effectively in the formal economy, and the emergence of true development plans at the municipal level.

Keywords: socio-economics, profitability, ornamental horticulture, Togo

\section{Introduction}

Many studies on the urban and peri-urban areas agriculture (AUP) (Mbaye, 1999; Fall, 2001; Moustier et Fall, 2004; Mougeot, 2005; Ba, 2007) show well the importance of this activity for the West African towns in particular. The products of this sector and their modalities of production represent an important stake in terms of jobs, incomes, diversity of vegetal species (Griffon, 2003; Radji et al., 2010) and the protection of the environment (Fall, 2001; Weinbergera et al., 2007). More particularly, the most deprived people find in this situation some opportunities to secure their means of existence (Ba Diao, 2004; Moustier, 2004; de Zeeuw et al., 2000).

Among the AUP's forms, ornamental horticulture constitutes in Togo, a true form of investment and creation of principal or additional incomes (Moustier, 2004) for the economic operators who work in the import-export sector. Besides, it constitutes a form of social insertion of the unemployed. However, its practice raises some concerns associated with the precariousness of the exploited spaces, public health with the uncontrolled use of the banned plant-care products and the technique in terms of modernity of the production systems (Cissé, 2000; Mbaye et Moustier, 2000; Akinbamijo et al., 2002).The alteration of the urban and peri-urban environment associated and induced with this activity constitutes the most visible impact. Consequently, the recognition of the horticultural activities still remains to conquer (spaces allocated by the municipal authorities to farmers) to bring politicians, namely those who deal with the urban and country planning, to take them into account in their urban planning policies (Fall et Fall, 2001).

In Togo, no statistics on the sector of ornamental horticulture exists although the need to inform the actors (public administration, farmers and researchers) and to give them necessary instruments for a good planning of this activity is considered necessary. These elements can 
allow the organization and development of the sector by making it contribute to the national economy and at the same time getting it out of the informal sector. It is therefore urgent to put at the disposal of the decision makers, the different elements allowing defining a strategy for the development of ornamental horticulture. It is within this framework that this present study, through surveys carried out on the different actors from the period 2005 to 2010, proposes to characterize the subsector of the horticultural ornamental production in Togo. In a more specific manner, the study consists of:

- making a typology of ornamental horticulture in Togo;

- analyzing the diversity of the production systems, their main constraints and their economic impacts. The results obtained will allow to say if ornamental horticulture is, yes or no, an underemployment in Togo;

- describing the situation of labor and its characteristics in order to allow the identification of the action avenues notably the training and the availability of qualified personnel, the specialization of the producers and the increase in production which can lead to export. The nature and the size of labor will give the situation of employment in the sector and its capacity to offer a lucrative activity and a social insertion opportunity.

\section{Materials and Methods}

The method of work is first of all a review of literature. A documentary research has been carried out in the ministries of (trade, agriculture, the promotion of the private sector and the town) and in the training and research institutes (INFA de Tové, Ecole Supérieure d'Agronomie and the Faculty of Science of the Université de Lomé). It concerned studies, reports, and diverse data published with the passing of years on the agricultural sector and that of research in Togo. There is in fact very little information on the ornamental horticulture sector which is defined here as the growing of ornamental plants. There is no recent statistics for the whole sector of production, marketing and services in ornamental horticulture.

A prospective study has permitted to identify and to index the horticultural farms in Togo. It consisted of some field missions in 21 principal towns of the country (picture 1). Samples of 25 inhabitants of different neighborhoods of the same town were asked on the existence of a garden of plants in their locality (that is, 525 people questioned). For each identified farm, the owner was informed about the subject of study and his consent was acquired through a verbal authorization.

In the identified farms, the questionnaire prepared was administrated to 55 farmers, 124 employees and 100 people from the customers met on the farms.

The characteristics of each site have been noted. The size of the farm was measured with a decameter $(\mathrm{X} \pm 10 \mathrm{~m})$; the corporate company obtained by observation of the billboards, the geographical situation was obtained by GPS (Global Positioning System). The following characteristics were obtained by a questionnaire addressed to the farmer: year of installation, age and the matrimonial status of all the participants (employer, spouse, and employee), number of employees, additional activities done, running and management of the farm, 
relations with the civil and social administrations and the tax system. The following were also noted : the information relative to the level of instruction, to the material of production used such as the gardening material, the material and the processing plant equipment, the maintenance and soil conditioning products like fertilizers (chemical and organic) and the plant-care treatment products, the acquisition and space exploitation method, the plants supply method, their cost, the invested assets and the sale of products in its different aspects namely the gross income of the fiscal year estimated by the farmer himself/herself.

The economic data collected allowed to establish three categories of annual farming account according to a classification made on the basis of surface areas. These accounts comply with the "minimal evaluation-system of the treasury" of the normalized financial statements of the West African accounting system (SYSCOA) and applied by the Internal Revenue Service (DGI) in Togo. They give an idea about the profitability of a company of the informal type. Indeed, to determine the profitability of an activity one has to take away the costs of production from the total value of production (gross profit) to obtain the result of the farm (annual net income). In this study, for the costs of production to be representative, the sum of the profitability takes into account the paying off of implements. The paying off, takes into account the physical erosion and the technical development. The life span of the equipment is varied and is according to the intensity of its use and maintenance. In this present study, linear depreciation is recommended, that is, to share uniformly the value that can be depreciated on the whole duration of use. Depending on the type of equipment, the duration varies between two and five years. The value of production was obtained in two ways. On the one hand, it was obtained from the information given by the farm operators and the employees during discussions, and on the other hand, by taking into consideration the average price fixed and obtained from farm operators, employees and customers questioned, and the quantities of seedlings sold. Those quantities represent the average of those obtained on the report of farm operators and employees and of those observed on the field. Within the framework of this study, the yield of the land $\left(\mathrm{Y}_{1}\right)$ is the quantity of the products obtained during a calendar year on the exploited portion. It is represented by the formula (Dupriez and de Leener 1983, 1987) $\mathrm{Y}_{1}=\frac{F}{s}$ with $\mathrm{P}=$ Production in number of seedlings and $\mathrm{S}=$ surface area $\left(\right.$ in $\left.\mathrm{m}^{2}\right)$.

The yield of the work $\mathrm{Y}_{\mathrm{w}}$ is represented by the formula $\mathrm{Y}_{\mathrm{w}}=\frac{\mathrm{Qp}}{N D}$ with $\mathrm{Q}_{\mathrm{p}}=$ quantity of (seedlings) young plants and $\mathrm{N}_{\mathrm{D}}=$ Number of working days spent to get that quantity (Dupriez and de Leener 1983, 1987).

For each chemical used, the indications such as the trade name and the purpose of its use were written down. Further information such as specification category, the active contents, the doses and frequencies of use were obtained from two licensed companies for the importation, conditioning and the distribution of phyto-pharmaceutical products in Togo. All this information has been checked from the secretariat of the Committee in charge phyto-pharmaceutical products at the Department of Agriculture responsible for the issuance of licenses. 


\section{Aacrothink Institute ${ }^{\mathrm{TM}}$}

The data obtained were processed with the software $\mathrm{R}$, language oriented towards the processing of data and statistical analysis.

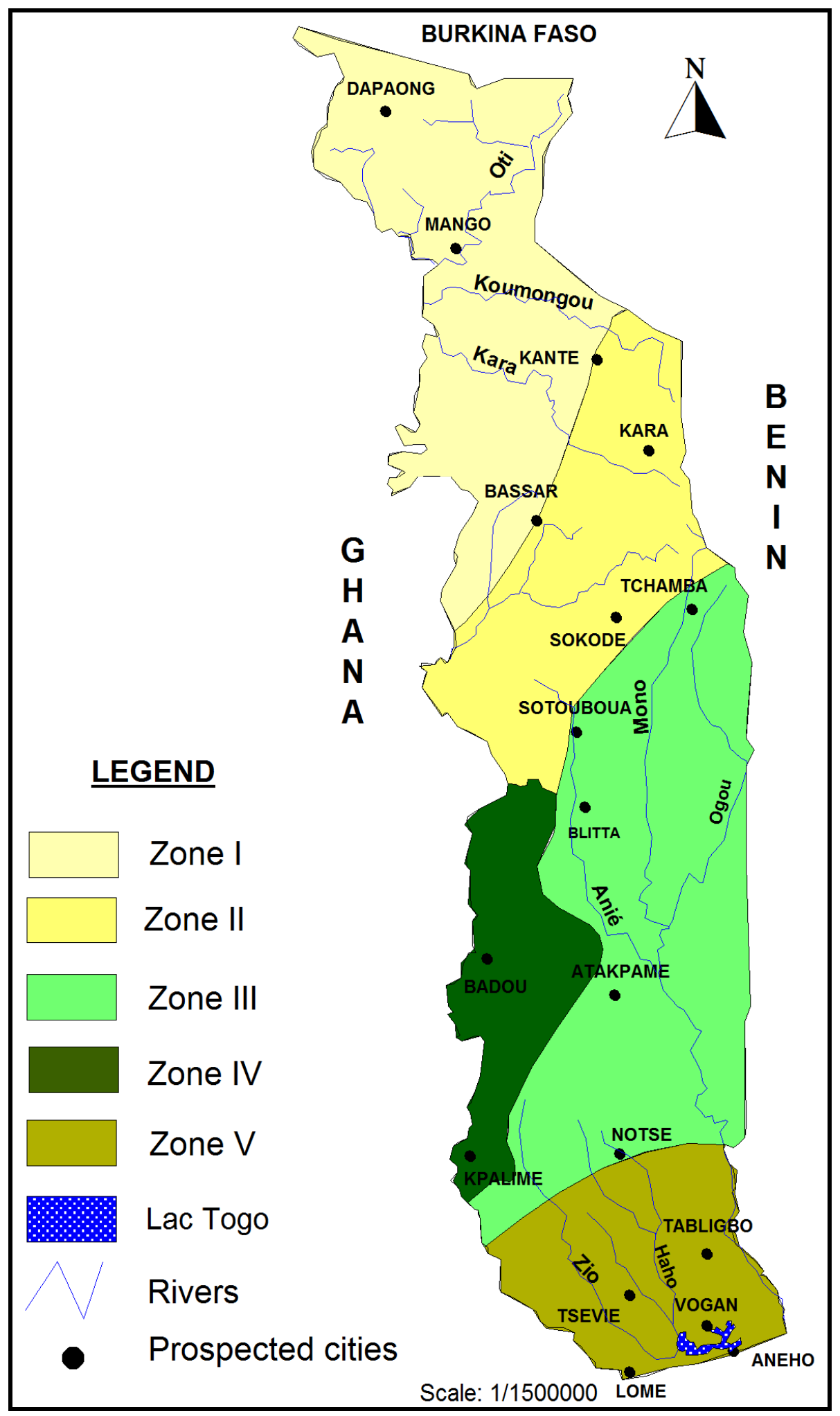

Figure 1. Eco-floristic subdivisions and prospected principal towns 


\section{MInstitute ${ }_{\text {Mnk }}^{\text {Macrothink }}$}

\section{Results}

\subsection{Number of Exploitations}

In October 2010, the number of horticultural exploitations listed in Togo was 55; their geographical distribution is summed up as follows: a farm in Atakpamé, another one in Kpalimé, and 53 others in Lomé and its environs. No other farm can be found in the other towns of the country. From 1997 to 2010, the number of horticultural farms (22 in Lomé in 1997) has increased by $66.66 \%$ and the extension of facilities is from 0 to 2 from Lomé towards the other towns of the country.
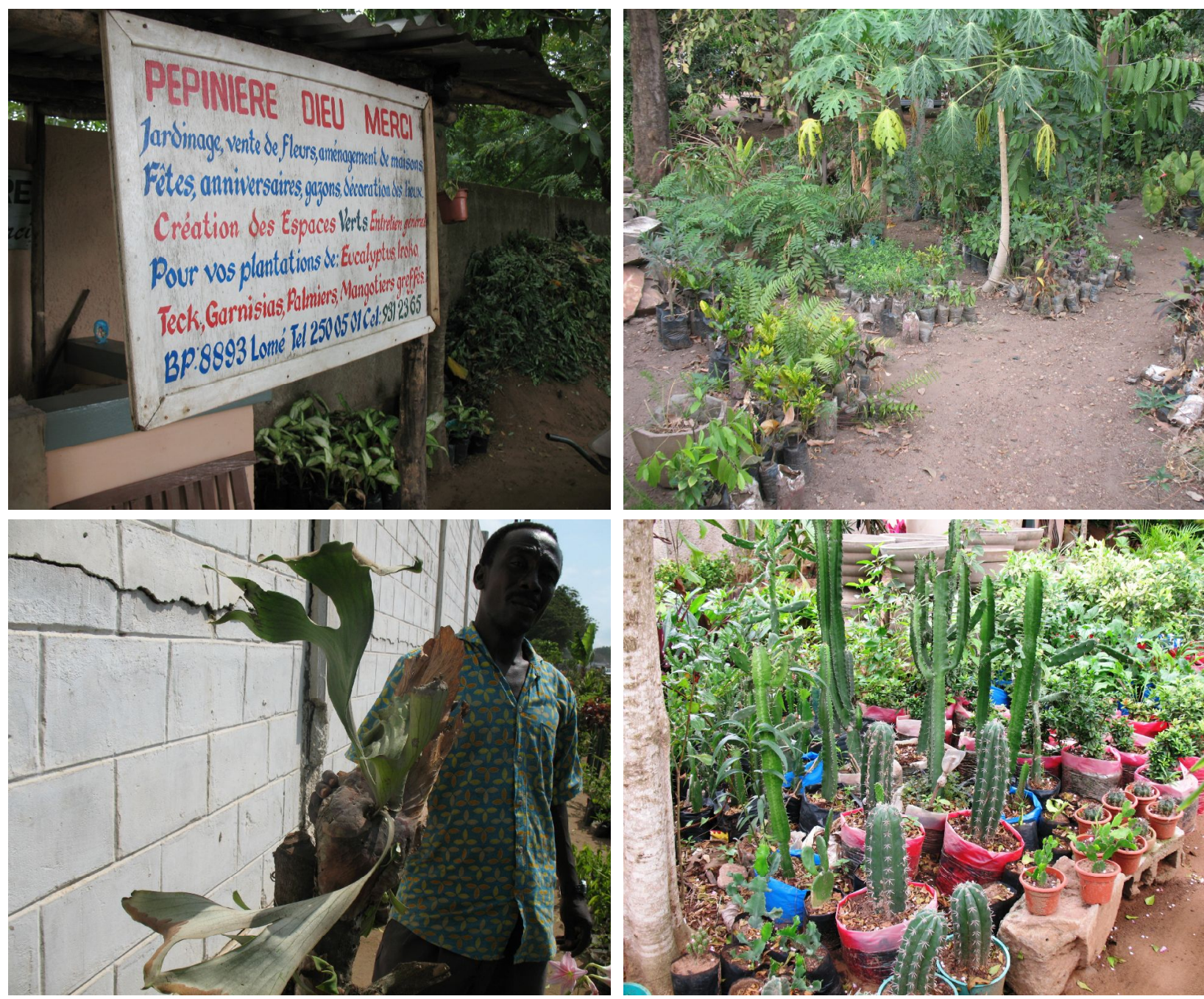

Picture 1. Horticultural farms with/without advertising plate

\subsection{Location of Farms}

They are set in different places (figure 2). Fifty-two (that is 94\%) of the farms are located in the «administrative reserves» belonging to the government and only three are set on individual private property. The administrative reserves are spaces meant for public utility services (playing grounds, schools, health facilities, etc.). In general, the farmers settle on 


\section{Macrothink}

these lands, occupy them illegally without a prior consent of the municipal authorities. Only three farms $(5.45 \%)$ declare taking possession of a land with tacit approval of the municipality but without having an official authorization for the occupation. The private lands belong to those exploiting them.

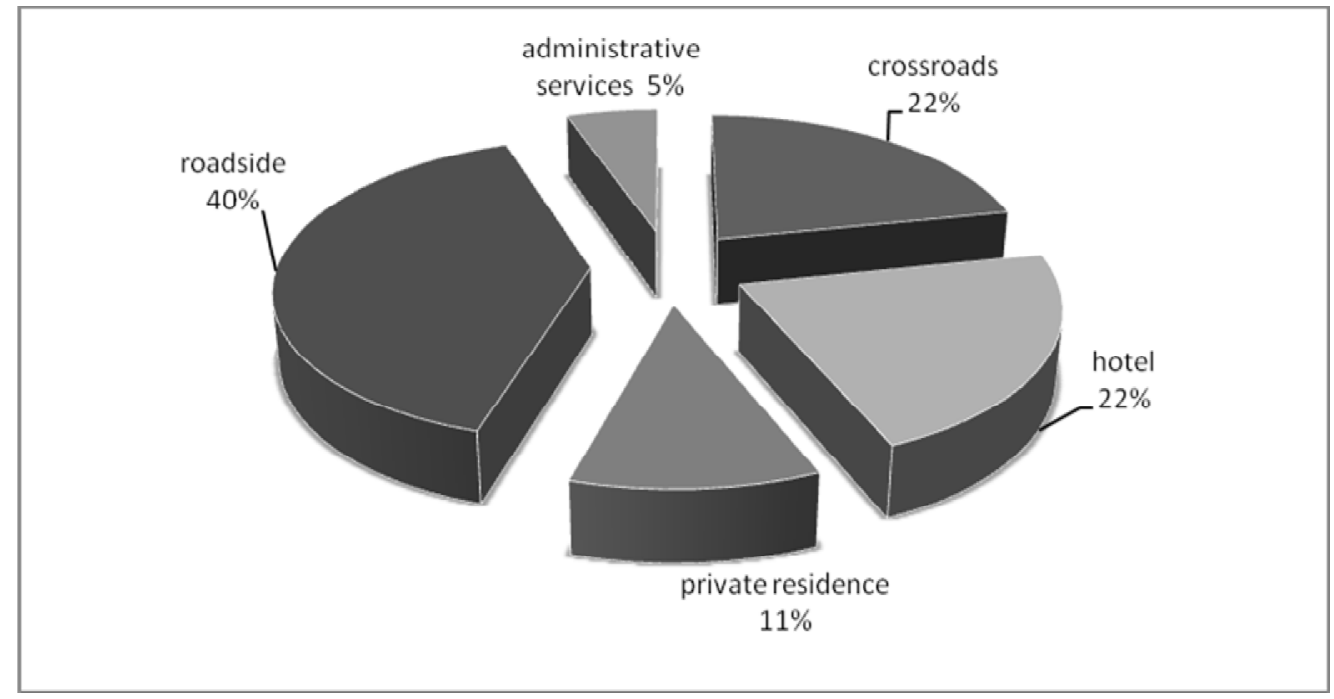

Figure 2. Distribution of nurseries according to places of installation

\subsection{Size of Companies}

More than $90 \%$ of the nurseries are private family farms. Their average size is $291.47 \mathrm{~m}^{2}$. On 55 identified lands, 7 have surface area above or equal to 6 are (100 square meters) whereas 8 have less than an are. The surface area of the biggest farm is $800 \mathrm{~m}^{2}$ whereas the smallest is $33 \mathrm{~m}^{2}$ (Figure 3). The gap (202.76) is very high, showing a great variability of the surface area of horticultural farms.

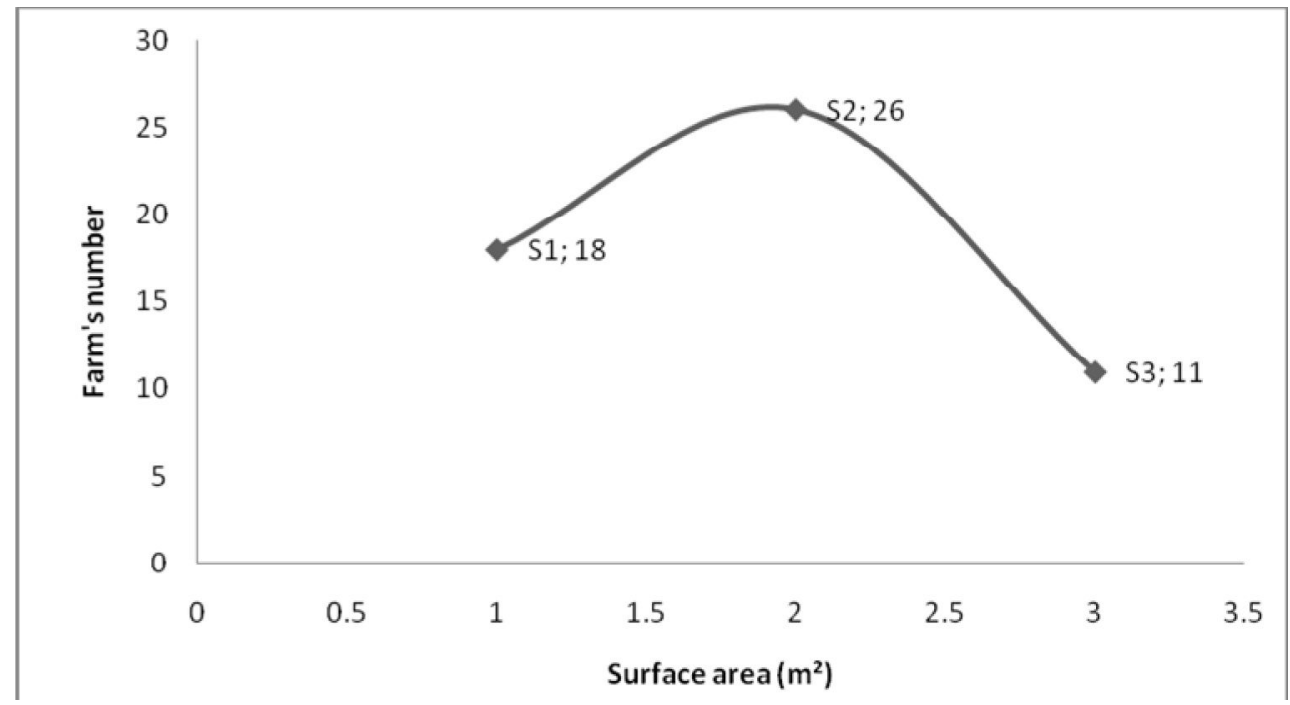

Figure 3. Distribution of farms according to dimensions $\left(\mathrm{m}^{2}\right)$

(The figures indicate the number of nurseries concerned, $\mathrm{S} 1=$ farms having less than $150 \mathrm{~m}^{2}$; $150<\mathrm{S} 2<500 \mathrm{~m}^{2} ; \mathrm{S} 3=$ farms having a surface area above $500 \mathrm{~m}^{2}$ ) 


\section{Macrothink}

\subsection{Number of Workers}

In October 2010, 179 people worked in the ornamental horticulture sector in Togo. We distinguished permanent manpower and temporary manpower. The permanent manpower represents $53.07 \%$, that is, a little more than half of the total manpower (Table 1).

Table 1. Distribution of horticultural manpower in Togo (October 2010)

\begin{tabular}{|l|c|c|c|}
\hline Locality & Permanent & Temporary & Total/Locality \\
\hline Atakpamé & 1 & 1 & 2 \\
\hline Lomé & 93 & 83 & 176 \\
\hline Kpalimé & 1 & 0 & 1 \\
\hline Total & $\mathbf{9 5}$ & $\mathbf{8 4}$ & $\mathbf{1 7 9}$ \\
\hline \multicolumn{1}{|c|}{} & $\mathbf{5 3 , 0 7}$ & $\mathbf{4 6 , 9 3}$ & $\mathbf{1 0 0}$ \\
\hline
\end{tabular}

Permanent manpower was predominantly male and formed $58 \%$ of the farmers themselves. Among the full time employees, we could count 5 women (that is 5.26\%) but none among the part time employees. The temporary manpower fully concentrated in Lomé (98.80\%) was composed of young people in search of daily income of subsistence. No girl was listed in that category.

\subsection{Age of Farm Operators and Employees}

The farm operators or farm lords were predominantly the youth : 44\% were less than 30 years old (Figure 4), 29\% aged between 30 and 55 years whereas $27 \%$ were more than 55 years. The oldest farm operator was 71 years old up to the study date. Besides, in the Togolese administration, the recorded age for retirement is 55 years.

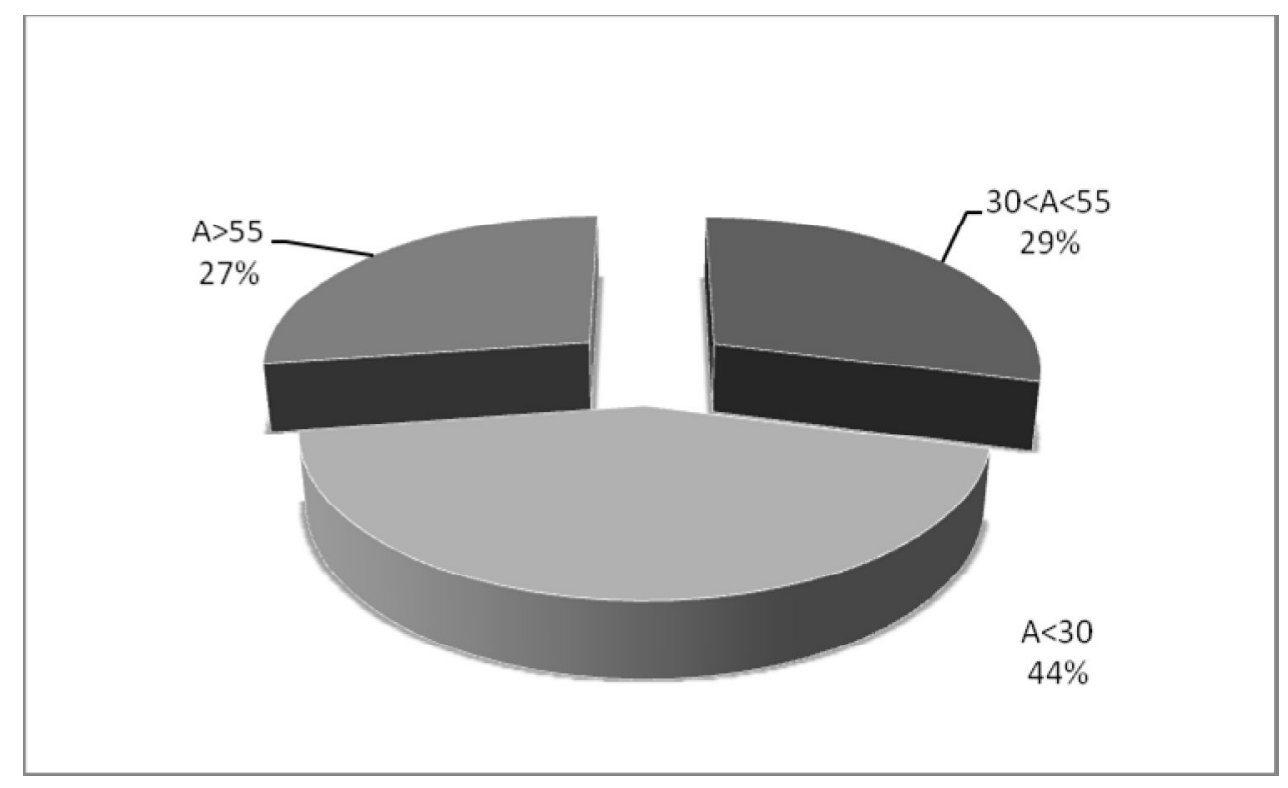

Figure 4. Age bracket of the farmers $(\mathrm{A}=\mathrm{age})$ 


\section{Macrothink}

Journal of Biology and Life Science ISSN 2157-6076 2013, Vol. 4, No. 1

All the farm operators employed permanently or temporarily 124 salaried employees including 65 (that is, 52.42\%) who were less than 30 years old and 19 (that is, 15\%) were more than 55 years (Figure 5).

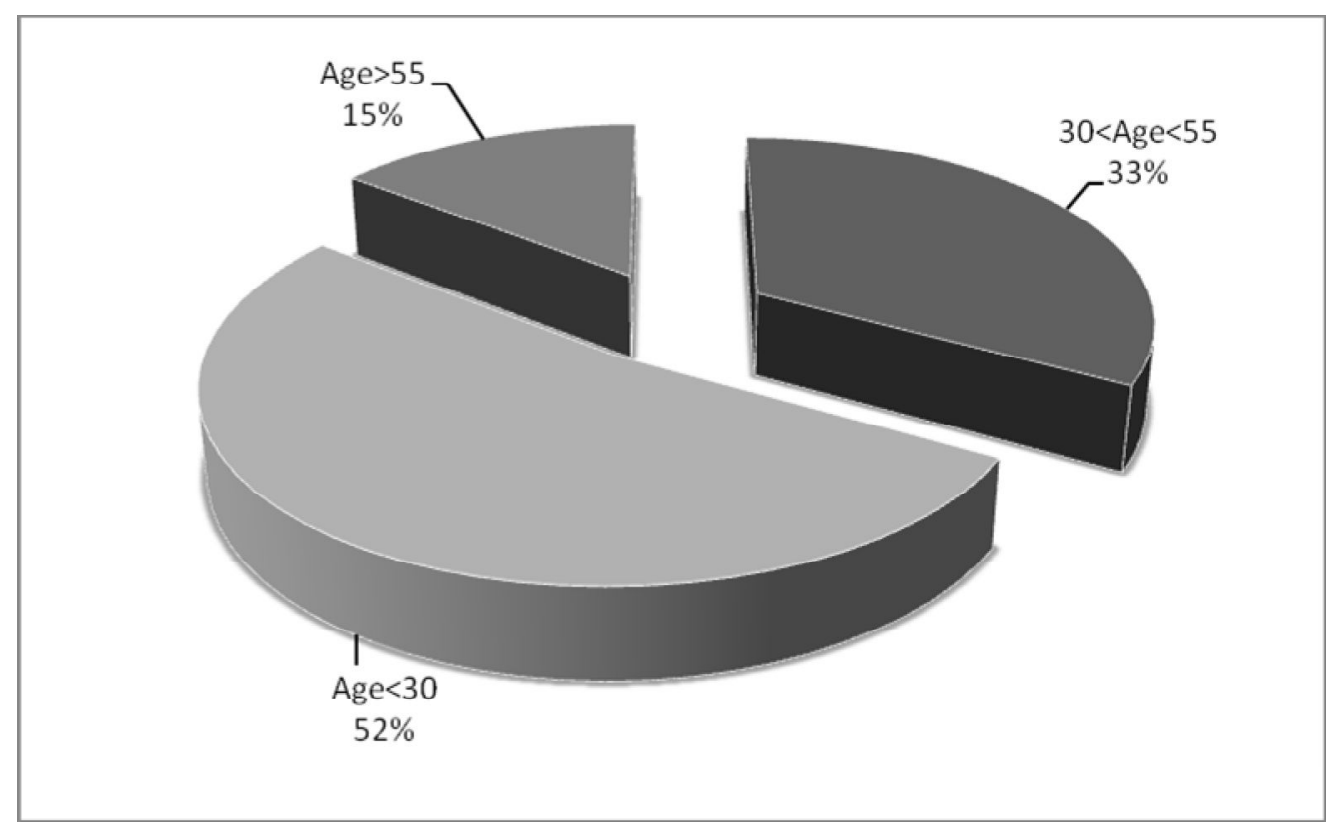

Figure 5. Age bracket of the employees $(\mathrm{A}=$ age $)$

\subsection{Civil Status of Workers}

In Togo, $87 \%$ of farmers and $42 \%$ of employees were married with at least a child. Single men represented $5 \%$ of farmers and $42 \%$ of employees. With regards to divorcees, they represented $4 \%$ of farmers and $2 \%$ of employees (Figure 6).

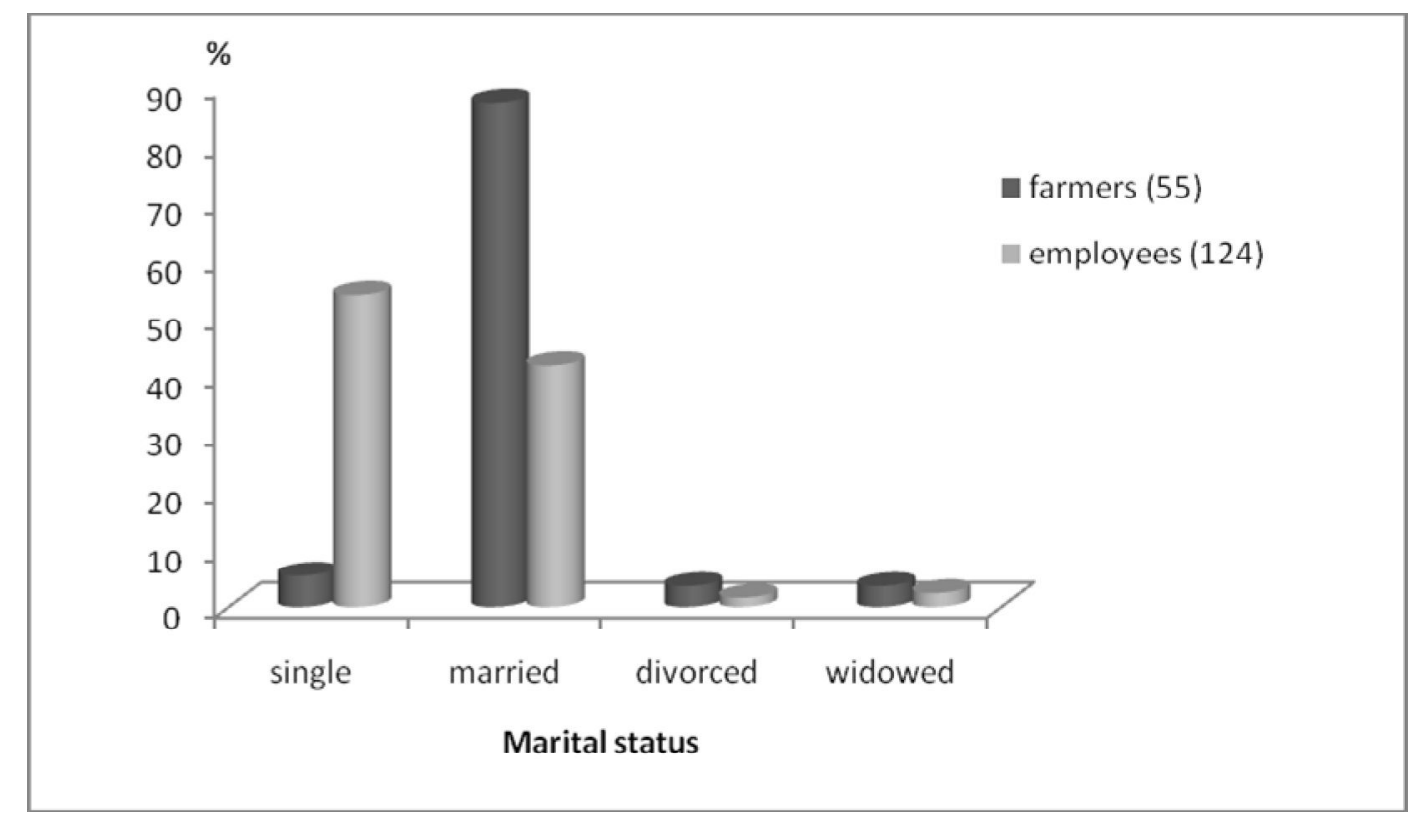

Figure 6. Civil status of employees in ornamental horticulture in Togo (October 2010) 


\section{Macrothink}

\subsection{Level of Education of Farmers and Employees}

Among the farmers, 19 (that is, 35\%) neither knew how to read nor write. Twenty-three (that is, $41.82 \%$ ) declared to have attended primary school up to class 5 or 6 (the final year) without obtaining the primary school leaving certificate. Thirteen $(23.64 \%)$ declared having attended junior high school and two maintained being holders of the Junior High School certificate (Figure 7). As far as temporary or permanent employees were concerned, around $51 \%$ (that is, 63) were illiterate, $49 \%$ attended primary school (40\%) or junior high school (9\%) without any attestation of their level in education (Figure 8).

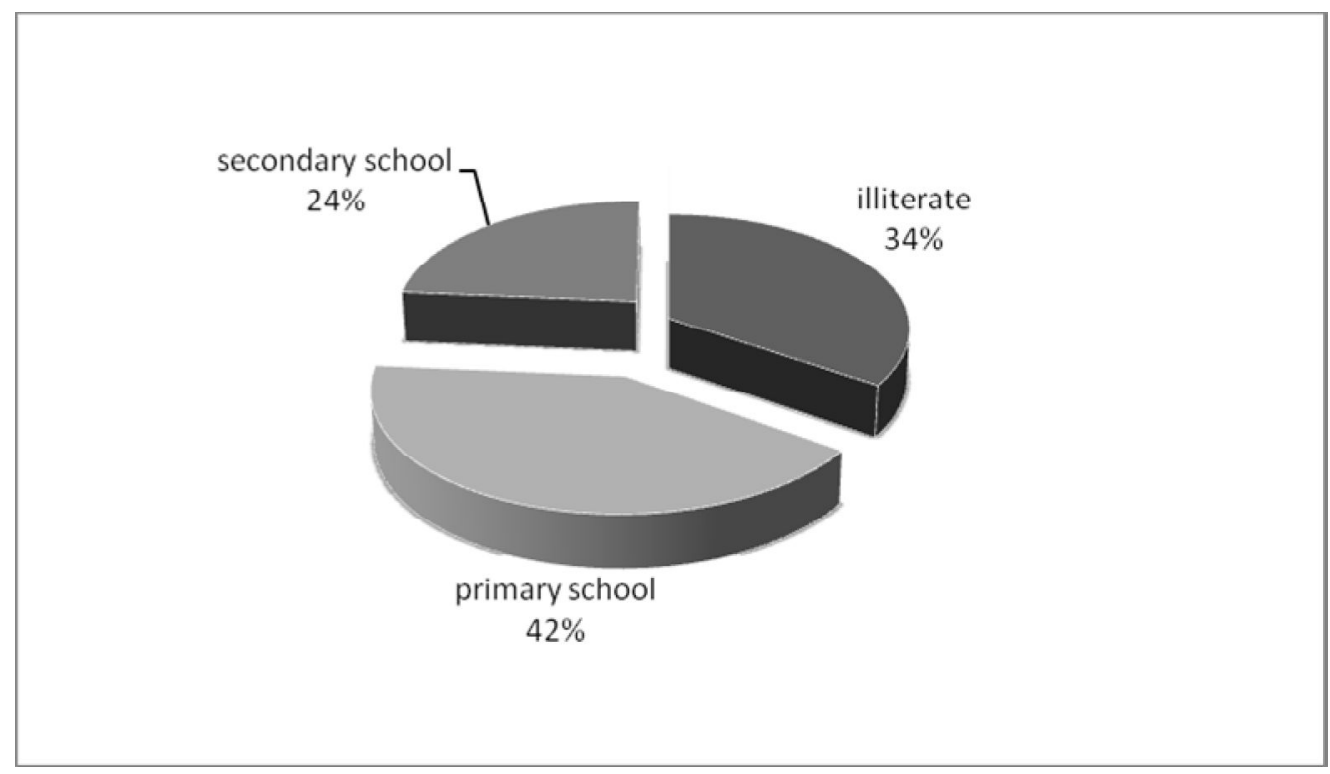

Figure 7. Level of education of employers

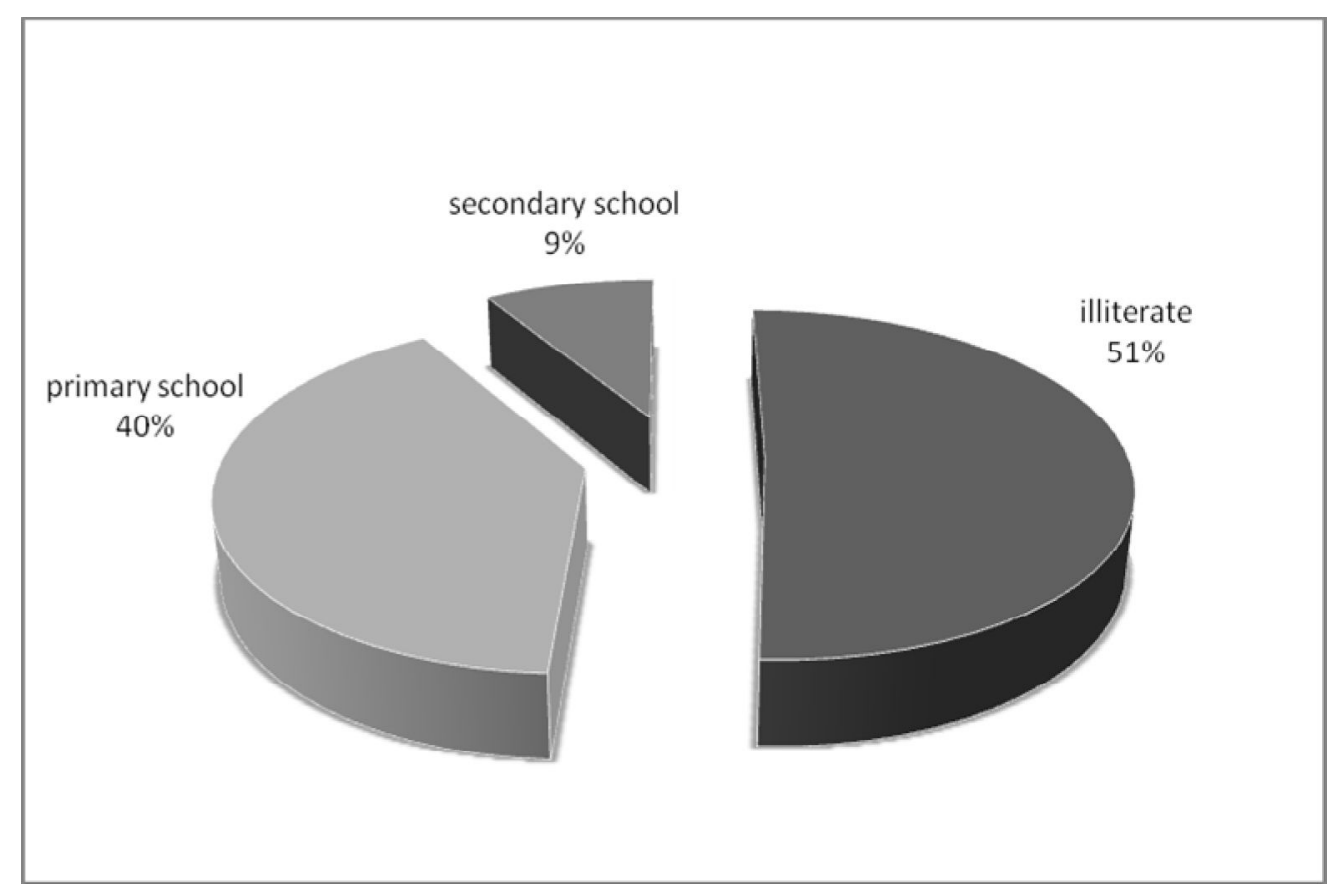

Figure 8. Level of education of the employed staff 


\subsection{The Assigned Activities}

Out of 55 farm owners, 50 (90\%) had a mixed activity in marketing (nurseries, arboriculture) and services. No employer was specialized in a particular subsector. The proposed or requested services by the private customers were the development and the maintenance of the landscaped residences, the maintenance of private playing grounds, the floristery and plant-care treatments. Those involved in the maintenance of the town's green spaces (that is, $8 \%$ of the 55 owners) worked as temporary employees of the municipality.

\subsection{Remuneration and Social Security Protection of Farmers and Employees}

The working day in the nurseries in Togo starts from 8 am to $6 \mathrm{pm}$ with a lunch break between $12 \mathrm{pm}$ to $2 \mathrm{pm}$. It is the same for the temporary workers who can also choose to do piece-work, working through lunch time from 6 am to 4 pm or still from 6 am to $2 \mathrm{pm}$ without interruption. The working week in the nurseries counts 6 days, from Monday to Saturday. The pay for the temporary employee is subject to the regular activity for which he is recruited, or to the days following the agreed hours when that activity requires his presence on many days (Table 2). For the permanent employees, the salary is weekly - and in this case, paid on Saturdays, biweekly or monthly (Table 3). No farmer has subscribed to any type of insurance neither for himself nor for an employee.

Table 2. Work tariffs in horticultural farms

\begin{tabular}{|c|l|c|}
\hline \multicolumn{2}{|c|}{ Activities } & $\begin{array}{c}\text { Daily amount } \\
\text { CFA Francs }\end{array}$ \\
\hline 1 & In farm : irrigation, filling bags, bagging, weed bags and pots planted & $400-600$ \\
\hline 2 & Services : grass seeding, weeding lawns, phytosanitary treatment & $800-1500$ \\
\hline
\end{tabular}

Table 3. Pay scale (CFA F) of employee's salaries by category of farms

\begin{tabular}{|rlrr|}
\hline & Weekly earnings & Monthly earnings \\
\hline - Category $1\left(\mathrm{~S}<150 \mathrm{~m}^{2}\right)$ & $1500-3000$ & $7000-10000$ \\
- Category $2\left(150<\mathrm{S}<500 \mathrm{~m}^{2}\right)$ & $2500-3000$ & $10000-12000$ \\
$-\quad$ Category $3\left(\mathrm{~S}>500 \mathrm{~m}^{2}\right)$ & $4000-6000$ & $15000-25000$ \\
For comparison $(\mathrm{SNU}, 2009)$ & & \\
$\quad-\quad$ Itinerant, seller, retailer of carrots and & vegetables & $10400-31200$ \\
$-\quad$ Guardian, Security guard & & $5000-20000$ \\
$-\quad$ Help or house servant & & $5000-18000$ \\
\hline
\end{tabular}




\subsection{Operating Profit}

Three cases of profit are presented according to the dimensions of the categories of farms. Indeed, the categories are defined according to the surface area of farms.

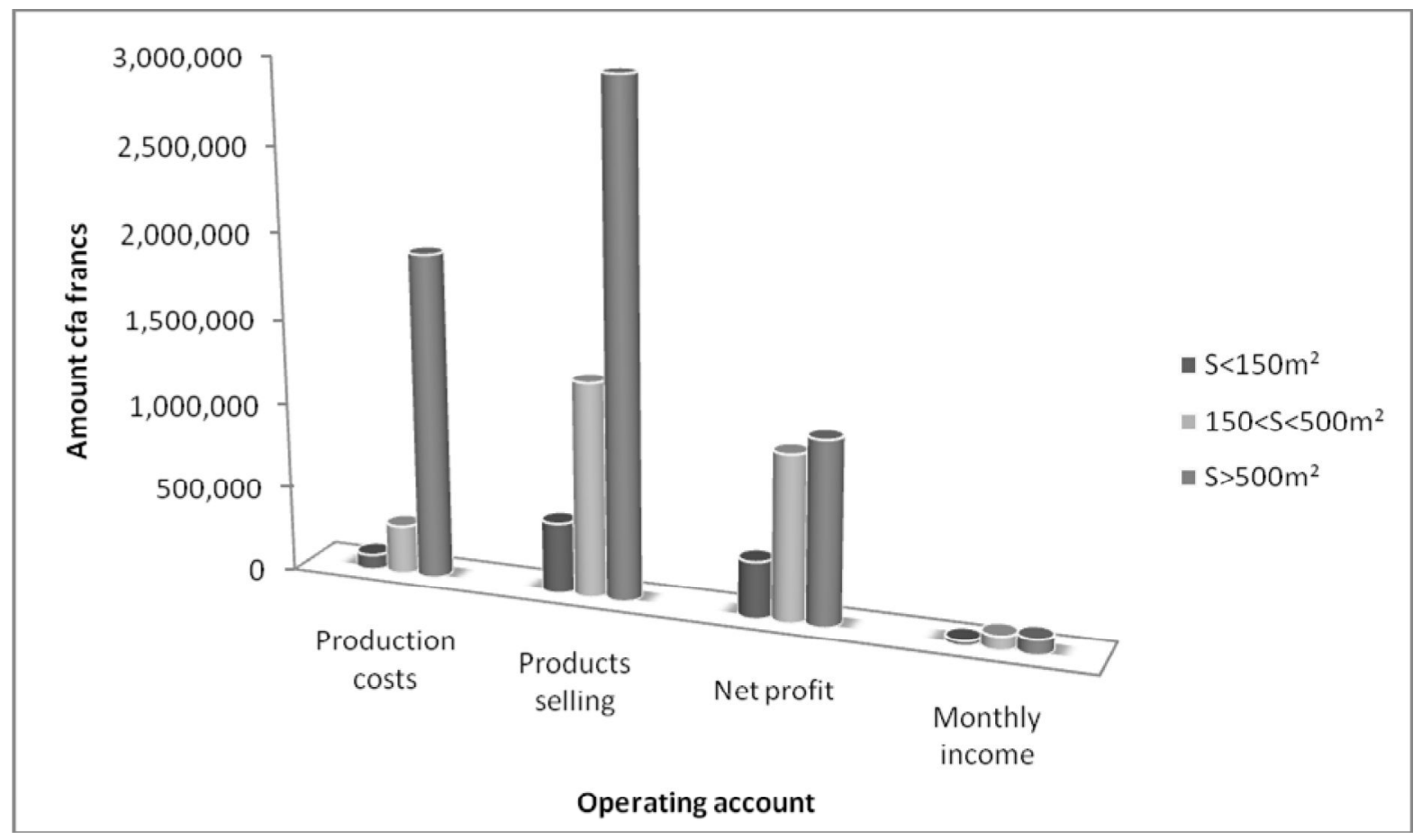

Figure 9. Profitability of horticultural farms according to the acreage

Following figure 9, the net income is according to the surface area of the farm and the diversity of products for sale. Indeed, when the surface area increases, the quantity of products for sale also increases. It is also applied to the monthly income. This can be explained by the fact that on a relatively big surface, the production of a species that is well sold is often provided in a great quantity.

\section{Discussion}

The current issues in the research for a better quality of life and the maintenance of the territory (Malakoff, 2007; Ba, 2007; Ambroise, 2004) have made people invest more and more in the sale of flowers. This trend should be maintained and even allowed to grow due to the cities expansion.

Ornamental horticulture in Togo is characterized by the use of cheap workforce, by small investments in production infrastructure, the use of locally made gardening implements (hoe, watering can, trowel, etc.) and the resort to the exploitation of small size farms (Aké Assi et al., 2010; Radji, 1998). Job seekers find with established operators, the employment of the work-class. Women also find there a job and can be used as unskilled workers, temporary or casual workers. (Aké Assi et al., 2002). Ornamental horticulture offers not only employment which is directly linked to it (Ba Diao, 2004) but it also generates and supports many other indirect activities in the craft sector and that of services (blacksmiths for the production of hoes, masons for the handmade pots, drivers for the transport of the plants, etc). Although the 
profit from these activities (only the sale of plants in the nurseries) is uncertain for beginners, it makes them live with a monthly income at least equal to the Guaranteed Individual Minimum Wage (GIMW) as fixed by the Togolese government and revised in August 2008 (CCM, 2008). The incomes are more important when the services of activities (installation and maintenance of private green spaces, spreading of pesticide or phytosanitary treatment of garden plants) are associated with the selling of ornamental plants (Kooten, 2008). The cultivation of plants is done throughout the year with the peaks of production in the rainy seasons. Plants are grown in sachets or in pots and this are not suitable for large scale marketing. This sector appears to be reserved for the deprived (Dembélé, 2001) because the feeling of contempt in the society for this kind of work is perceptible although it generates incomes (Ba Diao, 2004) as shown by the operating account.

Since 1997, this sector of activities has experienced an important development. The number of nurseries went up from 33 to 55 (Radji, 1998). That is how we have seen the setting up of many new production units and the development (increase in the surface area, recruitment of permanent workforce) of many existing businesses (Fall et Fall, 2001). It appears that the need to see the development of the horticultural sector is real but lack of qualified workforce has slowed down its expansion (Viguier, 2006). The producers, in majority illiterate and are less trained. It represents a brake on modernization, suitability to new technology, the ability to create and manage the producers' organization for the protection of their interests and the formalization of their relationship with suppliers, customers (Ba Diao, 2008) and the government. In fact, no company has employed a workforce with professional certificates in ornamental horticulture (IQRHH) even though this qualified workforce does not exist and all the employees play the different roles and work as supervisors or marketing agents. At present, the training aspect is overshadowed and the development of the sector is less envisaged. In fact, on the administrative side, the creation of an organization for the sector by the operators themselves or by the government is not in sight.

The basic educational system that exists in the public or private schools in Togo does not train or offer a qualified workforce to the horticultural sector in Togo. However, it is important to make sure that courses in ornamental horticulture are offered in institutions or schools where we have environmental programs. Courses in the institutions of higher education will also help improve the work in the sector. If it is admitted that horticulture and nurseries are sectors of activities with less consumers of workforce (Viguier, 2006) and that the know-how is transferred mainly on work situation, especially in small production units, the sector is highly opened to competition. The managers of these units should also be able to broaden their skills in business management. Training is indispensable in order to take into account the evolution of technologies, production processes and market requirements, logistics problems, organization of work, management of teams or the legal framework needed in obtaining plants (notably the exchange of plant material and the introduction of new plants). The training must then be an element of stimulation to the industry (Dembélé, 2001; Viguier, 2006). It can as well help to offer development possibilities to operators and employees working in the sector.

The registered firms have a size inferior to 0.1 hectares. This smallness hinders the 
development of the sector, its modernization and its competitiveness, making its contribution invisible to the formal sector (Niang and Stinghlamber; 2001; Nevena, 2009). The equipment is basic and the use of chemicals, particularly the fertilizers, is minimal. Farming is the main activity of the squatters or the illegal occupants of the lands.

The entrepreneurship of horticultural systems of production represents only $5.45 \%$ of horticultural activities, but it holds almost the whole public market because it has met the administrative formalities laid down by the municipal authorities and paid taxes. These are private businesses characterized by the employment of permanent salaried workers, the use of modern equipment (lawnmower, shears of hedges, motor sprayer). However, the employees are not specialized in the field of horticulture. Local consumption is the main destination of the production. The sector of ornamental horticulture in Togo is not yet directed towards exportation.

The cultivation of flower cuttings is quite technical and requires technical training. The big companies which operate in Africa belong to European groups that ensure the marketing in the European Union and participate in the big international exhibitions. Currently, the best way for an African horticulturalist to join this commercial network is subcontracting; he/she has to follow the example of what IQRHH (2003) recommended to Quebec horticulturalists. Indeed, it is a matter of setting businesses close to the big companies in order to benefit from their advice, technical assistance and markets without risking the depreciation of the goods during transportation and the search for a final customer. Organizing themselves in formal groups (FAD, 2007) is also a solution. Such a group is a success in many exporting countries of other products (coffee, cocoa, etc.) Government aid through the Chamber of Commerce and Industry to the organization of the sector is a necessity, a source, by no means insignificant, of foreign exchange for the producers and the state. Everything pleads in favor of this sector in Togo which has lands, workforce and climate for the development (reproduction and harvest) of crops along the year. What remains is the training of workers in technical skills.

\section{Conclusion}

Ornamental horticulture in Togo is characterized by the weakness of farm lands and the disorganization of the sector. It helps to meet partly the ornamental plants needs of the capital, to participate in generating direct and indirect incomes, to reduce partially unemployment and to embellish the environmental landscape of cities. The mode of acquisition and exploitation of spaces is precarious because the cities of the country and particularly Lomé (the capital) are implementing building projects especially road construction. The infrastructural development, as it is at present, has compelled operators on the Boulevard du Mono (Lomé Benin border) and public highways to move. Maintaining the balance between urbanization and ornamental horticulture is possible so long as the authorities concerned realize its importance in the improvement of the quality of urban life, in the supply of essence and ornamental diversities to towns, in the reduction of unemployment and its contribution to the national economy. It is important that all the stakeholders in the field have an integrated and concerted approach not only for the improvement of the system of production, but also for the 
consideration of horticultural concerns in the urban development plans.

Within the framework of the town embellishment policy, flowers can play a very important role. It is so necessary to undertake actions to allow the budding horticultural industry to play fully its role in this policy and in the country's economy. The training of a qualified workforce would be an asset for its development. In the end, a public service, notably the Chamber of Commerce and Trade, could take an interest in the sector and its concerns and give information on opportunities and horticultural products, in order to enhance the sector and make it more competitive.

\section{References}

Aké-Assi, E., Adou Yao, C. Y., Ipou Ipou, J., Neuba, D. F., Aké Assi, L., \& Traoré, D. (2010). Représentations des plantes ornementales pour les populations d'Abidjan et San Pedro, en Côte d'Ivoire. In: X. van der Burgt, J. van der Maesen \& J.-M. Onana (eds), Systématique et Conservation des Plantes Africaines. Royal Botanic Gardens, Kew, 289-296.

Aké Assi, A. E. (2002). Contribution à l'étude des plantes ornementales cultivées dans les régions d'Abidjan et de San-Pedro, en Côte d'Ivoire. Volume 1 - Textes et iconographies. Volume 2 - Catalogue illustré de 241 espèces et variétés horticoles. Th. Doct. $3^{\text {è }}$ cycle, Univ. Cocody (RCI), 242 p.

Akinbamijo, O. O., Fall, S. T., \& Smith, O. B. (2002). Advances in crop-livestock integration in West African cities. Dakar : ITC/ISRA/CRDI, 213 p.

Ambroise, R. (2004). Agriculture et paysage. Quelques bonnes raisons d'investir ce chantier. In Marcel O., dir., Le défi du paysage: un projet pour l'agriculture. Les Cahiers de la Compagnie du Paysage, $\mathrm{N}^{\circ}$ 3, 315 p, p. 151-162.

Ba, A. (2007). Les Fonctions reconnues à l'agriculture intra et périurbaine (AIPU) dans le contexte dakarois ; caractérisation, analyse et diagnostic de durabilité de cette agriculture en vue de son intégration dans le projet urbain de Dakar (Sénégal). Th. Doct., AgroParisTech et $\mathrm{UCAD}, 378 \mathrm{p}$.

Ba Diao, M. (2004). Situation et contraintes des systèmes urbains et périurbains de production horticole et animale dans la région de Dakar. Cahiers Agricultures, 13(1), 39-49.

Cissé, I. (2000). Utilisation des pesticides dans le système de production horticole dans la zone des Niayes : les produits et leurs impacts sur la nappe phréatique. Dakar, Th. Doct. $3 \mathrm{e}$ cycle, Ucad, $230 \mathrm{p}$.

CCM (Communiqué du Conseil des Ministres), (2008). Le SMIG et le SMAG revalorisés de plus de $100 \%$ [Online] Available: http://www.presidencetogo.com/index.php?option=com_content\&task=view\&id=248\& Itemid=76. (February 24, 2012).

Dembélé, D. (2001). Productions horticoles et perspectives de développement au Mali. Séminaire sur la diversification et le développement du secteur horticole en Afrique. Bamako, 
Mali, $11 \mathrm{p}$.

De Zeeuw, H., Gündel, S., \& Waibel, H. (2000). "The integration of agriculture in urban policies”. In Urban Agriculture Magazine, RUAF, 13-15.

Dupriez, H., \& De Leener, Ph. (1983). Agriculture tropicale en milieu paysan africain, Terres et Vie. ENDA, L'Harmattan ; 258-264.

Dupriez, H., \& De Leener, Ph. (1987). Jardins et vergers d'Afrique. Terres et Vie. L'Harmattan, APICA, ENDA, CTA, 18-22.

FAD (Fonds Africain de Développement) (2007). Projet de développement de la petite horticulture. Rapport d'évaluation. Département de l'agriculture et de l'agro-industrie, Kenya, 68 p.

Fall, S. T., \& Fall, A. S. (2001). Cités horticoles en sursis ? L'agriculture urbaine dans les grandes Niayes du Sénégal. Ottawa : CRDI, 140 p.

Gaye, M., \& Niang, S. (2002). Épuration des eaux usées et l'agriculture urbaine. Dakar: Enda Éditions, 354 p.

Griffon, M. (2003). Développement Durable, ensemble? Les enquêtes de Marie-Odile Monchicourt. Platypus Press. 129 p.

IQRHH. (2003). Diagnostic sur la main d'œuvre en horticulture ornementale au Québec. Secteur commercialisation et services. Rapport final, $91 \mathrm{p}$.

Kooten (van) O., 2008 - L'horticulture, source de richesse. [Online] Available: http://knowledge.cta.int/fr/Dossiers/Demandes-d-innovation/Introduction-au-dossier-sur-1-hor ticulture/Articles/L-horticulture-source-de-richesse. (December 24, 2009).

Kroll, R. (1992). Culture des fleurs à couper. CTA, Editions Maisonneuve et Larose. Paris. $16-20$.

Malakoff, D. (2007). What Good Is Community Gardening? [Online] Available: http://www.community garden.org/whatgood.php. (November 21, 2009).

Mbaye, A., \& Moustier, P. (2000). Market-oriented urban agricultural production in Dakar. In : Bakker N, Dubbeling M, Gndel S, Sabel-Koschella U, de Zeeuw H, éds. Growing Cities, Growing Food - Urban Agriculture on the Policy Agenda. Hambourg : DSE/ZEL, 235-256.

Mougeot, L. J. A. (2005). The Social, Political and Environmental Dimensions of Urban Agriculture. Agropolis IDRC, Ottawa, Canada, 286 p.

Moustier, P. (2004). Les fonctions et contraintes de l'agriculture périurbaine de quelques villes africaines (Yaoundé, Cotonou, Dakar). Cahiers Agricultures, 13(1), 15-22.

Moustier, P., \& Fall, A.S. (2004). «Les dynamiques de l'agriculture urbaine : caractérisation et évaluation ». In O.B. Smith, P. Moustier, L.J.A. Mougeot \& A. Fall., (Eds), Développement durable de l'agriculture urbaine en Afrique francophone. Enjeux, concepts et méthodes (à partir de l'atelier des 5 au 24 juin 2000, à Dakar). (23-29). CIRAD \& CRDI. 


\section{Macrothink}

Nevena, D., Oderab, M. M., Reardonc, T., \& Wang, H. (2009). Kenyan Supermarkets, Emerging Middle-Class Horticultural Farmers, and Employment Impacts on the Rural Poor. World Development, 37(11), 1802-1811. http://dx.doi.org/10.1016/j.worlddev.2008.08.026

Niang, I., \& Stinghlamber, G. (2001). Étude pour un programme de développement du secteur horticole au Sénégal. Rapport final. Dakar : Cabinet JEXCO, 71 p. + annexes.

Radji, R. Kokou, K., \& Akpagana, K. (2010). Etude diagnostique de la flore ornementale du Togo. Int.J. Biol. Chem. Sci, 4(2), 491-508.

Radji, R., Bouchet, Ph., \& Akpagana, K. (1998). La flore horticole du Togo. J. Bot. Soc. bot. France, 8, 87-94.

Regroupement des professionnels de l'horticulture ornementale (Reproh). (1997). Projet d'appui à la formation et à l'installation des producteurs de fleurs. Dakar: Reproh; 38 p. + annexes.

Seck, P. A. (1999). L'agriculture périurbaine dakaroise. Les enjeux de son suivi. In P. Moustier, A. Mbaye, H. De Bon, H. Guérin \& J. Pagès (Eds.) Agriculture périurbaine en Afrique subsaharienne. (141-147) Cirad Colloques. Montpellier : Cirad Éditions.

Viguier, M. (2006). Les perspectives économiques des secteurs de l'horticulture. Avis et rapports du Conseil Economique et Social. Paris, 184 p.

Weinbergera, K., \& Lumpkina, T. A. (2007). Diversification into Horticulture and Poverty Reduction: A Research Agenda. World Development, 35(8), 1464-1480. http://dx.doi.org/10.1016/j.worlddev.2007.05.002

\section{Copyright Disclaimer}

Copyright reserved by the author(s).

This article is an open-access article distributed under the terms and conditions of the Creative Commons Attribution license (http://creativecommons.org/licenses/by/3.0/). 